\title{
Factors associated with underweight among children of former-Kamaiyas in Nepal
}

\author{
Resham B. Khatri ${ }^{1}$ *, Shiva R. Mishra ${ }^{2,3}$, Vishnu Khanal ${ }^{3,4}$ and Bishnu Choulagai ${ }^{5,6}$ \\ ' Saving Newborn Lives Program, Save the Children, Kathmandu, Nepal \\ ${ }^{2}$ Monamohan Memorial Institute of Health Science, Kathmandu, Nepal \\ ${ }^{3}$ Nepal Development Society, Kathmandu, Nepal \\ ${ }^{4}$ School of Public Health, Curtin University, Perth, WA, Australia \\ ${ }^{5}$ Department of Internal Medicine and Clinical Nutrition, Institute of Medicine, University of Gothenburg, Gothenburg, Sweden \\ ${ }^{6}$ Department of Community Medicine and Public Health, Institute of Medicine, Tribhuvan University, Kathmandu, Nepal
}

\section{Edited by:}

Amit Agrawal, Gandhi Medical

College and Hamidia Hospital, India

Reviewed by:

Corrado Romano, IRCCS Associazione

Oasi Maria Santissima, Italy

Masamine Jimba, The University of

Tokyo, Japan

${ }^{*}$ Correspondence:

Resham B. Khatri, Child Health

Division, IMCl Section, Newborn Care

Secretariat, Teku, Kathmandu, Nepal

e-mail: rkchettri@gmail.com
Background: Bonded labor was a tradition in Nepal since the 16th century. In 2002, the Government of Nepal freed Kamaiyas and gave the newly freed individuals support for basic living. Many children of former-Kamaiyas live below subsistence level and are vulnerable to undernutrition. The aim of this study was to identify the factors associated with underweight among the children of former-Kamaiyas.

Methods: We conducted the community based cross-sectional study from June to December, 2012. Face-to-face interviews were conducted using semi-structured questionnaires with randomly selected mothers of 280 children under 5 years of age from former-Kamaiya families residing in Banke district. We also measured the weight and height of the children. Undernutrition was defined according to the World Health Organization child growth standards. Factors associated with underweight were examined using a Chi-square test followed by multiple logistic regression.

Results: Out of 280 children, 116 (41.4\%) were underweight ( $\leq 2$ SD weight-for-age), 156 $(55.7 \%)$ were stunted ( $\leq 2$ SD height-for-age), and 52 (18.6\%) were wasted ( $\leq 2$ SD weightfor-height). Females were more likely to be underweight than males [adjusted odds ratio $(\mathrm{aOR})=1.696,95 \%$ confidence interval $(\mathrm{Cl})=1.026-2.804]$. Children were less likely to be underweight if they were having daily bath $(\mathrm{aOR}=0.532 ; 95 \% \mathrm{Cl}=0.314-0.899)$ or if their mothers were $\geq 24$ years of age $(\mathrm{aOR}=0.440 ; 95 \% \mathrm{Cl}=0.266-0.727$ ).

Conclusion: The proportion of underweight, stunting, and wasting was more than the national average among the children of former-Kamaiyas. Female children were more likely to be underweight whereas children who were being bathed daily and with mothers whose age was $\geq 24$ years were less likely to be underweight.

Keywords: factors, Nepal, under five children, undernutrition, underweight

\section{INTRODUCTION}

The practice of bonded labor was centuries-old in Nepal. According to an old estimate, there were between 300,000 to 2,000,000 agricultural bonded laborers in 1993, mainly concentrated in the Far-Western Hill and Terai districts (1-3). There were mainly two forms of traditional agricultural bonded labor system, namely Haliya and Kamaiya $(1,2)$. The Kamaiya system was mostly prevalent in the Tharu community of western Nepal (4), whereas Haliya system was prevalent practice in various castes and ethnic groups across Nepal.

Tharu ethnic group constituted $6.6 \%(1,737,470)$ of the total population of Nepal in 2011. They are inhabitants of the Central and Western Terai (plain) regions, as well as the inner low lands (5). Poor Tharu people would make verbal agreements extending up to a year with rich landlords from other castes but they usually became indebted whilst fulfilling their families' basic needs, thus creating a multi-generational cycle of bonded laborers (1). Such laborers are called Kamaiyas and this system was primarily present in five western districts, namely Dang, Banke, Bardiya, Kailali, and Kanchanpur (1,2).

The Government of Nepal outlawed the practice of all forms of bonded labor by introducing the "Bonded Laborers (Prohibition) Act 2002," which freed the laborers in July, 2002. As a result, the 18,400 former-Kamaiya families mostly settled in Dang, Banke, and Bardiya. After more than one decade of their freedom, however, the former-Kamaiyas are among the most socioeconomically disadvantaged groups (6). When the Government of Nepal declared Kamaiyas free, thousands were evicted from their masters' homes and were deprived of access to land and work. Inadequate government support led many to live in the fields with no means of livelihood. Given that most of the former-Kamaiyas families are living under extreme poverty, with inadequate means 
of livelihood, and lack of food supplements, their children are vulnerable to undernutrition and other poor health condition.

Children who are underweight have low weight for their age, and this reflects a combination of chronic and acute malnutrition (wasting). Stunting reflects chronic nutritional deficiency (7). According to the Nepal demographic and health survey (NDHS) 2011, the prevalence of underweight, stunting, and wasting in children under 5 years of age was $40.3,56.0$, and $12.50 \%$, respectively, in the lowest wealth quintile compared to 10.0, 25.8, and $7.4 \%$, respectively, in the highest wealth quintile. In the MidWestern region, the respective prevalence was $36.9,50.3$, and $11.3 \%$ (8). A study on the Chepang community, a marginalized ethnic group, showed that $37.3 \%$ of children were underweight (9). The undernutrition status of children in other marginalized communities, such as the children of former-Kamaiyas have not been adequately investigated. Therefore, the objective of this study was to identify the factors associated with underweight among children under the age of five.

\section{MATERIALS AND METHODS STUDY SETTING AND PARTICIPANTS}

The study was conducted in a former-Kamaiyas settlement in Kohalpur village development committee (VDC) of Banke district in the Mid-Western Development Region of Nepal. Kohalpur VDC has 8173 households with 36,019 people (male:female $=0.94: 1$ ) (5). About $20 \%$ of the population in the VDC is illiterate and $68.0 \%$ of former-Kamaiyas are illiterate. Almost one-fifth of the population in the VDC are Tharu including former-Kamaiyas (5). The majority of the population depends on livestock $(52.9 \%)$ and manual labor work (21.9\%) for their livelihood. In 2005, the Government of Nepal settled 902 households of former-Kamaiyas in three settlement areas of this VDC. The government provided $170-2028 \mathrm{~m}^{2}$ of land for shelter per household (10).

\section{STUDY DESIGN AND SAMPLING}

We conducted a community based cross-sectional study from June to December, 2012. Face-to-face interviews were conducted with the mothers of children under the age of five using structured questionnaires. The list of children of former-Kamaiyas under the age of five was obtained from the local sub-health post. We calculated the sample size using the formula $(11)(n)=Z^{2} p q / d^{2}$ where $p$ is the national prevalence of underweight among children under 5 years of age in the lowest wealth quintile $=40 \%(8)$, $q=1-p=60 \%, d$ is the allowable error $=6 \%(11)$ and assuming a $10 \%$ non-response rate. Thus obtained sample size of 282 was selected from 902 households, using a systematic random sampling. The weight and height of children were measured. If there was more than one child in the family, the youngest child was included in the study. However, two mothers did not respond, so a total of 280 mothers were included in the analysis.

\section{MATERIALS AND DATA COLLECTION}

A structured questionnaire was adapted from the NDHS 2011 (8) and similar studies conducted in $\operatorname{Nepal}(9,12)$. The questionnaire was pre-tested in Ward 2 of Rajhena VDC in Banke district to test cultural adaptability. We conducted 2-day training for five enumerators on interview techniques, data collection, and anthropometric measurements (weight and height). Recumbent length was measured for children 0-23 months of age and standing height was measured for children 24 months and older (13). Calibration of the instruments was carried out prior to record height and weight. Height was measured to the nearest to $1 \mathrm{~cm}$. Weight was measured using a standardized calibrated Salter scale, which could detect mass to the nearest to $0.05 \mathrm{~kg}$. Two measurements were taken and averaged.

\section{MEASUREMENT OF VARIABLES}

Outcome variable of this study was underweight. According to the World Health Organization (WHO), underweight, stunting, and wasting are the $\mathrm{Z}$ score of weight-for-age (WAZ), height-for-age (HAZ), and weight-for-height (WHZ), respectively, defined by $\leq 2$ SD from the respective reference median (14).

Independent variables were demographic characteristics, breastfeeding history (early initiation of breastfeeding within $1 \mathrm{~h}$ and exclusive breastfeeding), pre-lacteal feeding (feeding the child liquids other than the mother's milk prior to initiating lactation), 24-h recall of dietary diversity in meals (cereals, legumes, dairy, meat, fish, vitamins, and fruits/vegetables), and health and sanitation factors (Vitamin A and Albendazole tablet consumption in the past 6 months, growth monitoring, hand washing of children before eating, and stool disposal).

\section{DATA ANALYSIS}

We entered the data in EpiData 3.1. Anthropometric scores were generated using the software, ENA for SMART. Data entered into EpiData and ENA for SMART were exported to SPSS 19.0 for further analysis. The undernutrition status and nutritional practices were reported as proportions. Chi-square tests of association between underweight and independent variables were examined. Variables which were significant at the $25 \%$ level in the Chi-square test were further investigated in multiple logistic regression (15) using a stepwise backward elimination procedure. $P$ values $<0.05$ were considered statistically significant in final multiple regression analysis.

\section{ETHICAL CONSIDERATIONS}

Ethics approval was obtained from the Institutional Review Board at the Department of Community Medicine and Public Health, Institute of Medicine, Tribhuvan University, Kathmandu, Nepal. Written approval was also given by the District Public Health Office, Banke and Kohalpur sub-health post. Participants also gave verbal informed consent.

\section{RESULTS}

\section{CHARACTERISTICS OF PARTICIPANTS}

Among the 280 mothers interviewed, the mean age was 24.0 (SD 4.8 ) years. The majority $(56.8 \%)$ of mothers could not read and write at all. The average size of households was 5.1 (SD 1.8). The birth interval between the last child and the preceding child was $>24$ months for the majority $(84.4 \%, n=154)$ of mothers. Only $12.5 \%$ mothers had monthly earnings. The majority (53.9\%) were living in the settlement for $\geq 7$ years. The daily expenditure on food in most of the households (61.1\%) was $<200$ Nepalese Rupees $(\leq 2$ USD). About $28 \%$ of mothers fed their children three or more types of food varieties as part of their typical daily meal (Table 1). 
Table 1 | Characteristics of respondent mothers $(n=280)$.

\begin{tabular}{|c|c|c|c|}
\hline Characteristics & Number (\%) & Underweight ${ }^{\mathrm{a}}(\%)$ & $P$ value \\
\hline Age of mother; mean: & & & $P=0.03$ \\
\hline \multicolumn{4}{|l|}{24.5 (SD: 4.8) years } \\
\hline$<24$ years & $157(56.1)$ & $53(33.8)$ & \\
\hline$\geq 24$ years & $123(43.9)$ & $63(51.2)$ & \\
\hline Family size; mean: & & & $P=0.34$ \\
\hline \multicolumn{4}{|l|}{5.0 (SD: 1.8) } \\
\hline $2-5$ & $187(66.8)$ & $90(43.1)$ & \\
\hline $6-10$ & $93(33.2)$ & $26(36.6)$ & \\
\hline $\begin{array}{l}\text { Years of schooling of } \\
\text { mother; median: <1 }\end{array}$ & & & $P=0.37$ \\
\hline \multicolumn{4}{|l|}{ [IQR: 0-6] years } \\
\hline$<1$ years & $159(56.8)$ & $73(54.9)$ & \\
\hline \multicolumn{4}{|l|}{ (no schooling-illiterate) } \\
\hline $1-8$ years & 50 (17.9) & $14(34)$ & \\
\hline$\geq 9$ years & $71(25.4)$ & $25(35.21)$ & \\
\hline Monthly earning & & & $P=0.85$ \\
\hline No & $245(87.5)$ & $101(41.1)$ & \\
\hline Yes & $35(12.5)$ & $15(42.9)$ & \\
\hline Duration of living in the & & & $P=0.11$ \\
\hline \multicolumn{4}{|l|}{ settlement; median: 7} \\
\hline \multicolumn{4}{|l|}{ [IQR: 4-9] years } \\
\hline $2-7$ years & $129(46.1)$ & $60(46.3)$ & \\
\hline $8-11$ years & $151(53.9)$ & $56(37.1)$ & \\
\hline Expenditure on food in the & & & $P=0.03$ \\
\hline \multicolumn{4}{|l|}{ past $24 \mathrm{~h}$; median: 2} \\
\hline \multicolumn{4}{|l|}{ [IQR: 1-3] US Dolor } \\
\hline 0-2 US Dolor & $171(61.1)$ & $62(36.3)$ & \\
\hline 3-10 US Dolor & 109 (38.9) & $54(49.3)$ & \\
\hline Food diversity ( $n=257)$ & & & $P=0.36$ \\
\hline$\leq 3$ Food stuffs & $185(72.0)$ & $81(43.8)$ & \\
\hline$>3$ Food stuffs & $72(28.0)$ & 27 (37.5) & \\
\hline Age of child; median: 27 & & & $P=0.55$ \\
\hline \multicolumn{4}{|l|}{ [IQR: 13-40] months } \\
\hline $0-11$ & $58(20.7)$ & $20(34.5)$ & \\
\hline $12-23$ & $53(26.1)$ & $33(45.2)$ & \\
\hline $24-35$ & $46(16.4)$ & $20(43.5)$ & \\
\hline $36-47$ & $62(22.0)$ & $23(37.1)$ & \\
\hline $48-59$ & 41 (14.6) & $20(48.8)$ & \\
\hline Sex of child & & & $P=0.09$ \\
\hline Male & $150(53.6)$ & $69(46.0)$ & \\
\hline Female & $130(46.4)$ & $47(36.2)$ & \\
\hline Birth interval of & & & $P=0.87$ \\
\hline \multicolumn{4}{|l|}{ child ( $n=154)$; mean: } \\
\hline \multicolumn{4}{|l|}{44.6 (SD: 21.2) } \\
\hline 10-24 months & $24(15.6)$ & $9(37.5)$ & \\
\hline 24-99 months & $130(84.4)$ & $51(39.2)$ & \\
\hline
\end{tabular}

$P$ value; Chi-square test of association, ${ }^{a}$ percentages indicate row percentage. $I Q R$, inter quartertile range.
Table 2 | Child feeding practices $(n=280)$.

\begin{tabular}{|c|c|c|c|}
\hline Characteristics & Number (\%) & Underweight $^{\mathrm{a}}(\%)$ & $P$ value \\
\hline $\begin{array}{l}\text { Colostrum feeding } \\
\text { practices }\end{array}$ & & & $P=0.37$ \\
\hline Fed to newborn & 259 (92.5) & $104(40.2)$ & \\
\hline Discarded & $21(7.5)$ & $12(57.1)$ & \\
\hline $\begin{array}{l}\text { Practices of prelacteal } \\
\text { feeding }\end{array}$ & & & $P=0.41$ \\
\hline No & 268 (95.8) & $111(41.0)$ & \\
\hline Yes & $12(4.3)$ & $4(33.3)$ & \\
\hline $\begin{array}{l}\text { Time of early } \\
\text { breastfeeding; median: } \\
0.5 \text { [IQR: } 0.5-1] \text { (h) }\end{array}$ & & & $P=0.07$ \\
\hline$<1 \mathrm{~h}$ & 232 (82.9) & $89(38.4)$ & \\
\hline $1-24 \mathrm{~h}$ & 36 (12.85) & $20(55.6)$ & \\
\hline$\geq 24 \mathrm{~h}$ & $12(4.28)$ & 7 (58.3) & \\
\hline $\begin{array}{l}\text { Feeding status of } \\
\text { children }\end{array}$ & & & $P=0.77$ \\
\hline Breastmilk only & $23(8.2)$ & $8(34.8)$ & \\
\hline $\begin{array}{l}\text { Breastmilk and solid } \\
\text { meal }\end{array}$ & 178 (63.6) & 74 (41.6) & \\
\hline Solid meal & $79(28.2)$ & $34(43.0)$ & \\
\hline $\begin{array}{l}\text { Termination of } \\
\text { breastfeeding }(n=79) \text {; } \\
\text { mean: } 32 \text { (SD: } 4.9) \\
\text { months }\end{array}$ & & & $P=0.34$ \\
\hline$\geq 21-32$ months & $37(46.8)$ & 18 (48.6) & \\
\hline 33-40 months & $42(53.2)$ & $16(43.0)$ & \\
\hline $\begin{array}{l}\text { Duration of exclusive } \\
\text { breastfeeding }(n=257) \text {; } \\
\text { mean: } 6.1 \text { (SD: } 0.9) \\
\text { months }\end{array}$ & & & $P=0.14$ \\
\hline $1-5$ months & $19(7.4)$ & 5 (26.3) & \\
\hline $6-9$ months & $238(92.6)$ & $103(43.3)$ & \\
\hline $\begin{array}{l}\text { Feeding practices } \\
\text { during illness }\end{array}$ & & & $P=0.22$ \\
\hline $\begin{array}{l}\text { As per interests of } \\
\text { child }\end{array}$ & $121(43.2)$ & 55 (45.5) & \\
\hline More than usual & 97 (34.6) & $32(33.0)$ & \\
\hline As usual & $36(12.9)$ & $17(42.2)$ & \\
\hline Less than usual & $26(9.3)$ & $12(46.2)$ & \\
\hline
\end{tabular}

$P$ value; Chi-square test of association, a percentages indicate row percentage. $I Q R$, inter quartertile range.

CHILD FEEDING PRACTICES

Eight percent of children did not receive colostrum. Only $4.3 \%$ children received pre-lacteal feeds. About $82.9 \%$ mothers started breastfeeding their newborns within $1 \mathrm{~h}$ of birth. More than half $(53.2 \%)$ of the mothers continued breastfeeding until the children reached 32 months of age. Similarly, $80 \%$ of mothers exclusively breast fed their children for 6 months. Less than half (43.2\%) of the mothers practiced child feeding on demand (Table 2 ). 


\section{HEALTH AND SANITATION PRACTICES}

Almost $65.7 \%$ of the children were not monitored for growth. A vast majority $(91.1 \%)$ of the children received Vitamin A and Albendazole (89.0\%) in the last 6 months. About $68.2 \%$ of the children washed their hands with soap and water before eating (Table 3).

\section{UNDERNUTRITION STATUS OF CHILDREN}

Of the 280 children, 116 (41.4\%) were underweight, 156 (55.7\%) were stunted, and $52(18.6 \%)$ were wasted (Table 4).

\section{FACTORS ASSOCIATED WITH UNDERWEIGHT}

A number of independent variables were associated with being underweight in Chi-square test of association. But in multiple logistic regression, only three variables were significantly associated. Female children had higher odds of being underweight compared to their male counterparts [adjusted odds ratio $(\mathrm{aOR})=1.696 ; 95 \%$ confidence interval $(\mathrm{CI})=1.026-2.804]$. On the other hand, children who were bathed daily had a lower likelihood of being underweight $(\mathrm{aOR}=0.532$; 95\% $\mathrm{CI}=0.314$ 0.899 ). Children whose mothers were $\geq 24$ years of age were less likely to be underweight $(\mathrm{aOR}=0.440 ; 95 \% \mathrm{CI}=0.266-0.727$ ) (Table 5).

\section{DISCUSSION}

The proportion of underweight, stunting, and wasting was 41.4, 55.7 , and $18.6 \%$, respectively. The proportion of undernutrition in this community was higher than the national average, and also higher than in the Mid-Western Terai districts of Nepal (8). This proportion is higher than other studies conducted in countries like Kenya, Serbia, and India $(8,13,16,17)$. The high proportion of undernutrition might be due to the overall poor socio-economic status of the study population. In Nepal, only a third of children receive the recommended amount of food (18). The poor feeding practices in this socially marginalized community may have contributed to higher undernutrition among children. It is an emergency situation in this community, which calls for urgent interventions (19).

More than $82 \%$ of mothers were found to initiate breast feeding within $1 \mathrm{~h}$ of childbirth. NDHS 2011 and the study conducted in Pokhara, Nepal, reported breastfeeding within $1 \mathrm{~h}$ of child birth at 44.5 and $43.5 \%$, respectively $(8,20)$. In our setting, such a high proportion of early initiation might be due to the cultural practice of initiating breastfeeding immediately after birth. The lower socio-economic status of this study group may be another factor that accounts for a high breastfeeding initiation rate as they may be unable to buy expensive pre-lacteal feeds (18). Likewise, the duration of exclusive breastfeeding was 6.1 months, which was higher than the national average (4.2 months) (8). However, this finding subjects to limitations of having long recall period. The current nutrition program of the Ministry of Health and Population of Nepal promotes exclusive breastfeeding up to the age of 6 months. Nepal's Breast Milk Substitute Act (1992) promotes and protects breastfeeding and regulates the unauthorized or unsolicited sale and distribution of breast milk substitutes (21). Introducing breast milk substitutes to infants before 6 months can contribute to breastfeeding failure and infections.
Table 3 | Health and sanitation practices $(n=280)$

\begin{tabular}{|c|c|c|c|}
\hline Characteristics & Number (\%) & Underweight ${ }^{\mathrm{a}}(\%)$ & $P$ value \\
\hline $\begin{array}{l}\text { Growth monitoring in } \\
\text { past } 6 \text { months }\end{array}$ & & & $P=0.14$ \\
\hline No & $184(65.7)$ & $82(44.6)$ & \\
\hline Yes & 96 (34.3) & $34(35.4)$ & \\
\hline $\begin{array}{l}\text { Vitamin A capsule } \\
\text { supplementation (6- } \\
59 \text { months) }(n=236)\end{array}$ & & & $P=0.46$ \\
\hline No & 21 (8.9) & $6(28.7)$ & \\
\hline Yes & $215(91.1)$ & $96(44.7)$ & \\
\hline $\begin{array}{l}\text { Albendazole distributed } \\
\text { children aged } \\
1-5 \text { years }(n=191)\end{array}$ & & & $P=0.16$ \\
\hline No & $21(11)$ & $9(42.8)$ & \\
\hline Yes & $170(89.0)$ & 73 (42.9) & \\
\hline $\begin{array}{l}\text { Hand washing with } \\
\text { detergents in the past } \\
24 \mathrm{~h}(n=220)\end{array}$ & & & $P=0.41$ \\
\hline No & 89 (31.8) & $40(44.9)$ & \\
\hline Yes & $131(68.2)$ & 76 (39.8) & \\
\hline $\begin{array}{l}\text { Child bathing practices } \\
\text { in the last } 7 \text { days }\end{array}$ & & & $P=0.02$ \\
\hline $\begin{array}{l}\text { Bathing in alternative } \\
\text { days }\end{array}$ & 87 (31.1) & $45(51.7)$ & \\
\hline Daily bathing & 193 (68.9) & $71(36.8)$ & \\
\hline $\begin{array}{l}\text { Disposal of children } \\
\text { stool in the past } 24 \mathrm{~h}\end{array}$ & & & $P=0.07$ \\
\hline Open defecation & $134(47.9)$ & $64(47.8)$ & \\
\hline Sanitary latrine & 75 (26.8) & $24(32.0)$ & \\
\hline Pit latrine & $71(25.4)$ & $28(39.4)$ & \\
\hline
\end{tabular}

$P$ value; Chi-square test of association,

apercentages indicate row percentage.

$I Q R$, inter quartertile range.

Table 4 | Undernutrition status of children $(n=280)$

Undernutrition Number $[\% ; 95 \% \mathrm{Cl}]$

NDHS 2011

status

\begin{tabular}{|cc} 
National (\%) & $\begin{array}{c}\text { Mid-Western } \\
\text { Terai region (\%) }\end{array}$ \\
\hline 29 & 32.1 \\
41 & 43.5 \\
11 & 7.5 \\
\hline
\end{tabular}

Our study found that only $4 \%$ of mothers had provided prelacteal feeds to their children. Pre-lacteal feeding practices are common in Nepal as it is culturally accepted in some communities $(18,22)$. Previous studies conducted in Nepal have revealed that the prevalence of pre-lacteal feeding ranges from 14 to $39 \%$ $(18,21,22)$. The Government of Nepal recommends colostrum 
Table 5 | Factors associated with underweight.

\begin{tabular}{|c|c|c|c|c|}
\hline Characteristics & OR $(95 \% \mathrm{Cl})$ & $P$ value & aOR $(95 \% \mathrm{Cl})$ & $P$ value \\
\hline Sex of child & & $P=0.09$ & & $P=0.04$ \\
\hline Male & 1 & & 1 & \\
\hline Child bathing practices in the last 7 days & & $P=0.02$ & & $P=0.02$ \\
\hline Bathed in alternative days & 1 & & 1 & \\
\hline$<24$ years & 1 & & 1 & \\
\hline$\geq 24$ years & $0.485(0.299-0.788)$ & & $0.440(0.266-0.727)$ & \\
\hline
\end{tabular}

OR, odds ratio, aOR, adjusted odds ratio, $\mathrm{Cl}$, confidence interval.

feeding practices. The practice of providing pre-lacteal feeds is discouraged because it limits the frequency of suckling by the infant and exposes the baby to the risk of infection (8).

We found that female children were more likely to be underweight. However, the likelihood of underweight was found lower in children whose mothers were $\geq 24$ years of age and those children who were bathed daily. A study from Ethiopia reported that male children were more likely to be underweight (23). Similar studies from other settings reported that the sex of the child was associated with the risk of undernutrition $(17,24)$. The frequency of bathing children may be taken as a proxy for general hygienic practices. The association between hygienic conditions and childhood diarrhea is well established (25). Our current findings support the idea that mothers who practice better hygiene by bathing their children frequently were less likely to be undernourished. Studies conducted in India and Bangladesh reported that children whose mothers were $<20$ years, were more likelihood to be undernourished $(24,26)$. Older mothers may be more able to care for their children. However, we did not examine other confounding factors such as number of illnesses the children suffered or quality of food and seasonal variation in such foods. Therefore, further research may be needed to include these variables.

This is the first study to explore the nutritional status among the children of former-Kamaiya families in Nepal. However, this study has a number of limitations. First, this was a cross-sectional study conducted in a small sample; the study might not be representative of all similar populations in Nepal. Recall bias may be a concern in nutritional practices of the mothers. Further research is needed to explore the ways to minimize undernutrition using cost-effective and sustainable technology.

\section{CONCLUSION}

The proportion of undernutrition among the children of formerKamaiya families was higher than the national average. Female children were more likely to be underweight. Children who were being bathed daily and born to mother's $\geq 24$ years of age were less likely to be underweight.

\section{ACKNOWLEDGMENTS}

We would like to thank Professor Dr. Bandana Pradhan, Prem Basel, and faculties of the Department of Community Medicine and Public Health, Institute of Medicine, Tribhuvan University,
Nepal for their guidance during the research process. We are also indebted to Shriya Pant for her support in the final editing of the paper. We would also like to thank the community leaders of former-Kamaiyas and all respondents of this study.

\section{REFERENCES}

1. Giri BR. Bonded labour practice in Nepal the promise of education as a magnet of child bondedness. South Asia Res (2010) 30(2):145-64. doi:10.1177/ 026272801003000203

2. Giri BR. The bonded labour system in Nepal perspectives of Haliya and Kamaiya child workers. J Asian Afr Stud (2009) 44(6):599-623. doi:10.1177/ 0021909609343414

3. Robertson A, Mishra S. Forced to Plough: Bonded Labour in Nepal's Agricultural Economy. London: Anti-Slavery International (1997).

4. Krauskopff G. Corvées (Begaari) in Dang: Ethno-historical Notes in Nepal: Tharu and Tarai Neighbours. Kathmandu: Mandala Book Point (1999). p. 47-62.

5. Government of Nepal, National Planning Commission Secretariat. National Population and Housing Census 2011. Kathmandu: Central Bureau of Statistics (2012).

6. Chhetri RB. The plight of the Tharu Kamaiyas in Nepal: a review of the social, economic and political facets. Occas Paper Sociol Anthropol (2005) 9:22-46.

7. Black RE, Allen LH, Bhutta ZA, Caulfield LE, de Onis M, Ezzati M, et al. Maternal and child undernutrition: global and regional exposures and health consequences. Lancet (2008) 371(9608):243-60. doi:10.1016/S0140-6736(07) 61690-0

8. Kumar S, Bhawani L. Managing child malnutrition in a drought affected district of Rajasthan-a case study. Indian J Public Health (2005) 49(4):198-206.

9. Subedi N, Paudel S, Rana T, Poudyal AK. Infant and young child feeding practices in Chepang communities. J Nepal Health Res Counc (2012) 10(21):141-7.

10. District Land Reform Office. Annual Report: Land Reform Activities in Banke District, Nepal. Banke: District Land Reform Office (2009).

11. Daniel W. Biostatistics: A Foundation for Analysis in the Health Sciences. New Delhi: Wiley India Pvt Ltd (2007). p. 185.

12. Gurung CK, Sapkota VP. Prevalence and predictors of underweight, stunting and wasting in under-five children. J Nepal Health Res Counc (2009) 7(15):120-6.

13. Olack B, Burke H, Cosmas L, Bamrah S, Dooling K, Feikin DR, et al. Nutritional status of under-five children living in an informal urban settlement in Nairobi, Kenya. J Health Popul Nutr (2011) 29(4):357-63. doi:10.1371/journal. pone. 0016085

14. Onis M. WHO child growth standards based on length/height, weight and age. Acta Paediatr (2006) 95(S450):76-85. doi:10.1111/j.1651-2227.2006.tb02378.x

15. Sun G-W, Shook TL, Kay GL. Inappropriate use of bivariable analysis to screen risk factors for use in multivariable analysis. J Clin Epidemiol (1996) 49(8):907-16. doi:10.1016/0895-4356(96)00025-X

16. Janevic T, Petrovic O, Bjelic I, Kubera A. Risk factors for childhood malnutrition in Roma settlements in Serbia. BMC Public Health (2010) 10(1):509. doi:10.1186/1471-2458-10-509

17. Kumar D, Goel NK, Mittal PC, Misra P. Influence of infant-feeding practices on nutritional status of under-five children. Indian J Pediatr (2006) 73(5):417-21. doi:10.1007/BF02758565 
18. Khanal V, Sauer K. Determinants of the introduction of prelacteal feeds in rural Nepal: a cross-sectional community-based study. Breastfeed Med (2013) 8(3):336-9. doi:10.1089/bfm.2012.0115

19. Collins S, Dent N, Binns P, Bahwere P, Sadler K, Hallam A. Management of severe acute malnutrition in children. Lancet (2006) 368(9551):1992-2000. doi:10.1016/S0140-6736(06)69443-9

20. Subba SH, Chandrashekhar TS, Binu VS, Joshi HS, Rana MS, Dixit SB. Infant feeding practices of mothers in an urban area in Nepal. Kathmandu Univ Med J (KUMJ) (2007) 5(1):42-9.

21. Chandrashekhar TS, Joshi HS, Binu VS, Shankar PR, Rana MS, Ramachandran U. Breast-feeding initiation and determinants of exclusive breast-feeding-a questionnaire survey in an urban population of western Nepal. Public Health Nutr (2007) 10(02):192-7. doi:10.1017/S1368980007248475

22. Khanal V, Adhikari M, Sauer K, Zhao Y. Factors associated with the introduction of prelacteal feeds in Nepal: findings from the Nepal Demographic and Health Survey 2011. Int Breastfeed J (2013) 8(1):1-9. doi:10.2286/17404358-8-9

23. Demissie S, Worku A. Magnitude and factors associated with malnutrition in children 6-59 months of age in pastoral community of Dollo Ado district, Somali region, Ethiopia. Sci J Public Health (2013) 1(4):175-83. doi:10.11648/J.SJPH. 20130104.12

24. Mittal A, Singh J, Ahluwalia SK. Effect of maternal factors on nutritional status of 1-5-year-old children in urban slum population. Indian J Community Med (2007) 32(4):264-7. doi:10.4103/0970-0218.37691
25. Khanal V, Bhandari R, Karkee R. Non medical interventions for childhood diarrhoea control: way forward in Nepal. Kathmandu Univ Med J (KUMJ) (2013) 43(3):256-61.

26. Nahar B, Ahmed T, Brown KH, Hossain MI. Risk factors associated with severe underweight among young children reporting to a diarrhoea treatment facility in Bangladesh. J Health Popul Nutr (2010) 28(5):476-83.

Conflict of Interest Statement: We declare that we do not have competing interest. First author presented the abstract of this paper at the third national nutrition symposium held in Kathmandu on 18-20 November 2014.

Received: 16 November 2014; accepted: 09 January 2015; published online: 29 January 2015.

Citation: Khatri RB, Mishra SR, Khanal V and Choulagai B (2015) Factors associated with underweight among children of former-Kamaiyas in Nepal. Front. Public Health 3:11. doi: 10.3389/fpubh.2015.00011

This article was submitted to Child Health and Human Development, a section of the journal Frontiers in Public Health.

Copyright (C) 2015 Khatri, Mishra, Khanal and Choulagai. This is an open-access article distributed under the terms of the Creative Commons Attribution License (CC $B Y)$. The use, distribution or reproduction in other forums is permitted, provided the original author(s) or licensor are credited and that the original publication in this journal is cited, in accordance with accepted academic practice. No use, distribution or reproduction is permitted which does not comply with these terms. 